\title{
Transformation of M. Zoshchenko's Plots in the Soviet Literature of the Thirties
}

\author{
Aleksander I. Kuliapin* \\ Altai State Pedagogical University \\ 55 Molodezhnaia, Barnaul, 656031, Russia
}

Received 23.01.2015, received in revised form 17.02.2015, accepted 28.04.2015

\begin{abstract}
M. Zoshchenko's stories of the twenties gave rise to a great number of imitations in mass fiction. Semiofficial writers of the 1930s also often appealed to Zoshchenko's stories, trying to transform them so that they match the ideological canons of the Stalin era. Thus, M. Kol'tsov includes a variation on the theme of Zoshchenko's "Podarok" ("Rasskaz o Podletse") / "The Gift" ("The Story of the Scoundrel") in his keynote speech on the problem of Soviet satire at the First Soviet Writers' Congress (1934). At that the conceptual point of Zoshchenko's story is reduced, a complete story turns into a rough draft for a newspaper feuilleton based on concrete material. Another example of the Soviet-style deconstruction of Zoshchenko's plot can be found in Kol'tsov's essay "Three days in a taxi" (1934). "Slight experience" in testing for the Soviet citizens' honesty is inspired by Zoshchenko's story "Na Zhivtsa" ("Chestnaia grazhdanka") / "With Whitebait" ("Honest Citizen"). Bait packages, Zoshchenko's and Kol'tsov's characters catch thieves with, look very similar but fundamentally differ in their concepts. This serves the evidence of a significant difference in the writers' views on human nature of the Soviet era.
\end{abstract}

Keywords: plot, text, motif, symbol, sign, model.

DOI: 10.17516/1997-1370-2015-8-7-1390-1395

Research area: philology.

\section{Introduction}

M. Zoshchenko's popularity in the 1920s was unprecedented. And since the writer was far enough from the Soviet ideology the semiofficious criticism was given the task to minimize his impact on reading masses by any means. Soviet critics failed to perform this mission. They could not cope with it as their main method of calling names and direct insults was quite ineffective. Zoshchenko was branded as "a bourgeois and a philistine" (A. Gurshtein), "a narcissistic cynic" (V. Ermilov), "a decadent", "a preacher of the lack of principles" (L. Plotkin), "a vulgar man", "a hooligan" (A. Zhdanov), etc. According to a figurative expression of one of the critics of the late twenties, Zoshchenko is only able "to chime bad jokes and utter slander on his melancholic triangle" (Ol'shevets, 1994, 151). These spells were apparently aimed not at the readers but mainly at the writer. For Zoshchenko to stop being the most widely read author of the Soviet Union it was necessary to debate with him on his territory, in his language. This was impossible to do without his fellow writers.

(c) Siberian Federal University. All rights reserved

* Corresponding author E-mail address: iskander58@mail.ru 


\section{The model}

\section{of Zoshchenko's texts transformation}

However, the first who worked at discrediting Zoshchenko was Zoshchenko himself. In the 1930s, when he re-published his stories of the previous decade he quite often spoiled them, trying to adapt them to the realities of the Stalin era.

A vivid example of his concessions to ideological pressure is "The Last Story" from "The Blue Book", which was published earlier under the titles "Electrification" (1924) and "Poverty" (1927).

The choice of "Electrification" title for a satirical story is defiant and provoking. Semen Kurochkin who is the narrator in the original version is well aware of the relevance and significance of a seemingly small incident in one of the communal flats.

"What, brothers, is today's most fashionable word? Today's most fashionable word of all is, of course, 'electrification'. Lighting up Soviet Russia with light, without doubt, is a matter of massive importance. No one can argue with it. But it does, for the time being, have its downside" (Zoshchenko, 1991, 220). Semen Kurochkin dares to get into an argument with, neither more nor less, Lenin, his GOELRO plan and his famous formula: "Communism is Soviet power plus the electrification of the whole country..." (Lenin, 1970, 30).

H.G. Wells in his book "Russia in the Shadows" (1920) wrote that Lenin "has succumbed to the Utopia of the electricians" (Wells, 1970, 104). According to "the Father of Science Fiction", the plan of the electrification of the whole country could not be implemented because its "application to Russia is an altogether greater strain upon the constructive imagination" (Ibid., 105). Zoshchenko's opinion was even more pessimistic. The problem was not in the lack of scientific and technical base in Lenin's project but in the specifics of human nature. In his "Electrification" Zoshchenko outdid Leonid Andreev, another glorified pessimist. In L. Andreev's sensational story "Darkness" (1907) the hero-revolutionary proclaimed: "If we cannot illuminate all the darkness with our lanterns, let's extinguish the lights and go down into the darkness" (Andreev, 1990, 298). The saddest thing is that Zoshchenko's characters can illuminate the darkness but, nevertheless, prefer to go back into the mist. By the light of the Ilyich's lamp the characters of the story reveal "foulness and filth", that "it's enough to make one shout blue murder" (Zoshchenko, 1991, 220-221). It is not surprisingly that the landlady Elizaveta Ignat'evna cuts the wire after a very short period of her life with light: "I don't want, she says, to live with light" (Ibid., 221).

The final part of "Electrification" still reserves some opportunity for "a ray of light in the realm of darkness" to be installed again: "All our life should be turned into a new one. For cleanliness and order to be around. For foulness and filth to be got rid of. All what is good in the dark turns bad when the light is on. Am I right, brothers?" (Ibid., 221). In 1927 Zoshchenko is more categorical. He crossed out five sentences and, thus, his story "Poverty" is hopeless in its final phrase: "Light's all very well, brothers, but it's not easy to live with" (Zoshchenko, 2000, 301).

In "The Last Story" the plot of "Electrification" changes beyond recognition. At the very beginning Zoshchenko strictly localizes the incident in time, attributing all ills to the accursed tsarist past, which is quite Soviet-style: "It was in the early years of the revolution when such an extraordinary incident took place in our house. The house is huge. With five floors. But despite this, it is with kerosene lighting, which is a sort of a gift to revolution, you might say, from the tsarist regime" (Zoshchenko, 1994, 438). 
Still, the main is saved for the most effective statement: electricity magically changes not only life but also all his characters' psychology and even physiology. Thus, in particular, the insane love of a responsible lodger, Elisaveta Ignat'evna Khlopushkina, and a technician, Anatoly Skorobogatov, is attributed by many characters to the effect of the electric light. "Actually the life, full of interests and understanding each other, began with the light. This is what happened after the installation of a general light supply", concludes the author (Ibid., 439-440).

In his "Blue Book" Zoshchenko outlined the model of transformation of his texts of the twenties. It seemed productive. Basing on the plot of Zoshchenko's one or another early story, the Soviet writers of the thirties rewrote it in accordance with new party and state directives.

\section{Conceptual basis of the research}

M. Kol'tsov was probably the most loyal to Zoshchenko among Soviet writers. However, his attitude to the author of "The Blue Book" perfectly fits the model of "the anxiety of influence" proposed by Harald Bloom (Bloom, 1998). In H. Bloom's terminology Kol'tsov is an "ephebe" seeking to outdo his predecessor "whom he admires, fears and envies at the same time. The ephebe covets to prove his superiority over the predecessor, to kill him as an artist with intentional, though partly subconscious, wrong reading of his texts and rewriting them in his own manner in order to master the art on his own terms" (Pratt, 1996, 6).

\section{Discussion}

Kol'tsov started his speech at the First Soviet Writers' Congress with a variation on Zoshchenkian theme: "Two and a half years ago Leningrad driver Martynov stole his comrade's, driver Tikhonravov's, chauffeur's book from the jacket. In Tikhonravov's absence he took his car, drove into town and got drunk. When drunk, he took the girls he was familiar with and while driving them ran over a dairymaid. During the potocoling Martynov called himself Tikhonravov's name. Having come back, he quietly parked the car on its place. After the incident was learnt about and Martynov's crime was revealed, there was a meeting in the garage. One part of those present at it demanded to immediately fire Martynov and expel him from the trade union. Others were not only for his firing and expelling from the trade union but also for his arrest. The third, the most bloodthirsty ones, demanded: "Martynov should be found and taken to Zoshchenko for the latter to write a story about him"'" (Kol'tsov, 1990, 221).

By the time of this speech Zoshchenko had already written a story about a man who called himself with a false name at the militia. In early 1934 Zoshchenko published the story "Gift" in "Crocodile" magazine (No. 3). The plot was similar. (Later Zoshchenko titled this story "The Story of the Scoundrel" which was one of the stories in his "Blue Book".) Kol'tsov could hardly fail to read this story because in 1934 he became the chief editor of "Crocodile". His keynote speech on Soviet satire was delivered the same year.

In his speech Kol'tsov does not mention the story "Gift" but the similarity of the two stories is so vivid to be accidental. Kol'tsov puts Zoshchenko's plot in reality, accurately indicating time and place of the incident, calling the participants' names. Zoshchenko reacts the opposite way. He notes that the story is based on real events but he does not mention "the scoundrel's" name: "Taking into consideration that the fact is real as well as a character himself, we would not like to mention his name in press" (Zoshchenko, 1994, 312).

Kol'tsov turned back the course of the creative process: a complete piece of writing 
is turned into a rough draft for a newspaper feuilleton. At that there is nothing left from Zoshchenko's main concept.

The similar way of transformation of another Zoshchenko's plot is Kol'tsov's essay “Three days in a taxi" (1934). As if in passing Kol'tsov dwells upon the experiment he carried out after 3 days of working as a taxi driver. "I forgot to mention a slight experiment I made the last day. I put a small package, wrapped in a newspaper, onto the back seat of the car. There was a key, a shoe brush, two apples and Turgenev's "Notes of a Hunter" in it. Four clients did not touch it. $<\ldots>$ But the young people snaffled the package smoothly and secretly" (Kol'tsov, 1957, 518).

Kol'tsov's "slight experience" is clearly inspired by Zoshchenko's "Na Zhivtsa" ("With Whitebait") (1925, originally the story was titled "Chestnaia grazhdanka" ("Honest Citizen")). This story was published in "Begemot" ("Hippopotamus") magazine (1925, No. 11) in which Kol'tsov was an active employee. This package in Zoshchenko's story also serves a litmus test for Soviet citizen's honesty.

Unlike Kol'tsov Zoshchenko's “honest citizen" does not make experiments but hunts with the whitebait. "I might just want to catch a thief with this package...", she admits (Zoshchenko, 2000, 398). The heroine does not doubt the universal depravity - everyone can turn out to be a thief. And she's right. A man with an empty bottle busily asks "What is there in the package?" not for nothing (Ibid.). He is a potential thief. The narrator who unwittingly disturbed such acting "with the whitebait" does it not out of his strong honesty. He firmly believes in inevitability of stealing any thing if it is left unkept even for a moment.

The contents of superficially similar packages are totally different. "Honest citizen" takes quarry on garbage. She "purposefully puts bones-and-rags stuff" in the package: "A thief does not make out what is in it. But he pilfers and pilfers everything that comes to hand" (Ibid.). In Zoshchenko's stories any thing can be an object of theft. For example, in the story "Bochka" ("The Barrel") people steal rotten cabbage which some cooperative was going to take out to scrapyard. Zoshchenko's heroine thinks a package with bones-and-rags stuff is also a contemporary's simplified image: nothing valuable can be discovered in his inner world.

Kol'tsov is not so severe in judging a Soviet citizen of the thirties. He tempts his clients with things which are quite suitable for practical use.

However, in both cases semiotics of things is much more important than their pragmatics. Zoshchenko's world is actually filled not only and not so much by things but their signs. In Kol'tsov's package, too, there is one thing that one can never use directly. It is a key. A passenger will never know what lock it fits, what door it opens. This key is semiotic. It indicates that a symbolic message a writer sends to an unknown reader has got its code which is easy to decrypt. An apple in Christian tradition is linked with the motifs of temptation and fall. The artists if they chose the plot of the expulsion from Paradise depict the forbidden fruit as a pomegranate or, more frequently, an apple. A book is a source of knowledge. Thus, it is predictably depicted next to the fruits of the tree of knowledge. Turgenev's "Notes of the Hunter" is a possible hidden reference to Zoshchenko's story about real hunting "with the whitebait". Finally, a brush is a transparent symbol of purification. Overall, Kol'tsov's message to "young fast livers" (Kol'tsov, 1957, 518), who have set a slippery rolling of an innocent petty theft, comes to a strong recommendation to increase the level of their culture: outer (one needs a brush here) and inner (one will not do without classic book here). Kol'tsov perfectly remembers a well-known maxima - "everything should be beautiful in a 
human: clothes, soul and thoughts". His package contains a minimum set of things necessary for that "reconstruction of human material" (Iu. Olesha) that was planned in the 1930ies.

\section{Conclusion}

In the article "To the humanists" (1930) M. Gorky formulated the Soviet understanding of the nature of culture. Probably, he did it better than others: "Culture is violence towards humans' zoological instincts which is organized by their mind" (Gorky, 1953, 239). This definition is close to Zoshchenko since his worldview and creativity are based on "the poetics of mistrust" (Zholkovskii, 1999), on a deep prejudice against human nature.

The epilogue of Zoshchenko's final work the book "Pered voskhodom solntsa" ("Before sunrise") - ends quite Gorky-style. The writer narrates about the crime of a Voronezh peasant who hacked his neighbor's family out of revenge: “The neighbours' quarrel was an old one, and now this peasant far gone with a rabid hatred finally committed his bloody crime" (Zoshchenko, 1994, 691). This story becomes Zoshchenko's last argument in his dispute with the opponents of the "necessity to control the mind": "...the thoughts in this letter (the letter of the Voronezh peasant to Zoshchenko. - A.K.) are so clear and so terrible that I consider it my duty to thrust on them my ideas of need for directing oneself, controlling one's feelings. It is not good when inferior forces get the upper hand. Mind should always win" (Ibid., 691).

Zoshchenko appeals to mind as the last means in the fight against "humans' zoological instincts". In his artistic world the only means of a human's improvement is a total control over him. In this respect Zoshchenko as a writer is even more Soviet than Kol'tsov.

\section{References}

1. Andreev L. T'ma [Darkness]. Sobranie sochinenii: v 6 t. T. 2 (Collected works: in 6 vol. Vol. 2). Moscow: Khudozhestvennaia literatura, 1990. Pp. 265-309.

2. Bloom H. Strakh vliianiia. Karta perechityvaniia [The anxiety of influence]. Ekaterinburg: Publishing house of the Ural University, 1998. 352 p.

3. Gorky M. Gumanistam. [To the humanists]. Sobranie sochinenii; v 30 t. T. 25 (Collected works: in 30 vol. Vol. 25) Moscow: GIKhL, 1953. Pp. 235-241.

4. Kol'tsov M. Tri dnia v taksi. Izbrannye proizvedeniia: v 3 t. T. 1 [Three days in a taxi. Selected works: in 3 vol. Vol. 1]. Moscow: Politizdat, 1957. Pp. 509-519.

5. Kol'tsov M.E. Rech na I Vsesoiuznom c'ezde sovetskikh pisatelei [Speech at the First Soviet Writers' Congress]. Pervyi vsesoiuznyi c'ezd sovetskikh pisatelei. Stenograficheskii otchet (The First Soviet Writers' Congress. Verbatim record). Moscow: Soviet writer, 1990. 718 p.

6. Lenin V.I. Rech na Moskovskoi gubernskoi konferentsii RKP(b) 21 noiabria 1920 g. [The Speech at the Moscow province conference of the RCP(b) on November 21, 1920]. Polnoe sobranie sochinenii. T. 42 [Complete works. Vol. 42]. Moscow: Politizdat, 1970. Pp. 17-38.

7. Ol'shevets M. Obyvatel'skii nabat (o "Sentimental'nykh povestiakh" M. Zoshchenko) [A philistine alarm (On M. Zoshchenko's "Sentimental stories"). Litso i maska Mikhaila Zoshchenko (Face and mask of Mikhail Zoshchenko). Moscow: Olimp, 1994. Pp. 148-152.

8. Pratt S. Garol'd Blum i "Strakh vliianiia" [Harold Bloom and "The Anxiety of Influence"]. New literary observer, 20, (1996), 5-6.

9. Wells H.G. Rossiia vo mgle [Russia in the Shadows]. Moscow: Progress, 1970. 224 p. 
10. Zholkovskii A.K. Mikhail Zoshchenko: poetika nedoveriia [Mikhail Zoshchenko: poetics of mistrust]. Moscow: Languages of Russian Culture, 1999. 392 p.

11. Zoshchenko M.M. Uvazhaemye grazhdane: Parodii. Rasskazy. Fel'etony. Satiricheskie zametki. Pis'ma k pisateliu. Odnoaktnye p'esy [Dear citizens: Parodies. Stories. Feuilletons. Satirical notes. Letters to the writer. One-act plays. Moscow: Knizhnaia palata, 1991. 664 p.

12. Zoshchenko M. Sobranie sochinenii v 3 t. T. 3 [Collected works in 3 vol. Vol. 3]. Moscow: TERRA, 1994. $720 \mathrm{p}$.

13. Zoshchenko M. Sochineniia. 1920-e gody: rasskazy i fel'etony. Sentimental'nye povesti. M.P. Siniagin. Ranniaia proza [Essays. The 1920-ies: Stories and feuilletons. Sentimental stories. M.P. Siniagin. Early prose]. Saint-Petersburg: Crystal, 2000. 1072 p.

\title{
Трансформация сюжетов М. Зощенко \\ в советской литературе тридцатых годов
}

\author{
А.И. Куляпин \\ Алтайский государственный \\ педагогический университет \\ Россия, 656031, Барнаул, ул. Молодежная, 55
}

Рассказы М. Зощенко 1920-х годов породили иельй шлейф подражаний в массовой беллетристике. Официозные писатели 1930-х годов также нередко обращались к сюжетам Зощенко, пытаясь трансформировать их таким образом, чтобы они соответствовали идеологическим канонам сталинской эпохи. Так, М. Кольцов в свою программную речь о задачах советской сатиры на Первом съезде писателей (1934 год) включает вариацию на тему рассказа Зощенко "Подарок» («Рассказ о подлеще»). При этом обобщающий смысл произведения Зощенко редуцируется, законченный рассказ превращается в черновую заготовку для газетного фельетона на конкретном материале. Еще один пример деконструкиии по-советски сюжета Зощенко можно найти в очерке Кольцова «Три дня в такси» (1934). «Маленький опыт» по проверке советских граждан на честность навеян очеркисту рассказом Зощенко «На живиа» ("Честная гражданка»). Пакеты-приманки, на которые герои Зощенко и Кольчова ловят воров, очень похожи внешне, но их содержимое принципиально отличается. За этим стоит различие в представлениях писателей о сущности человека советской эпохи.

Ключевые слова: сюжет, текст, мотив, символ, знак, модель.

Научная специальность: 10.00.00 - филологические науки. 